\title{
Glyphosate commercial formulation negatively affects the reproductive success of solitary wild bees in a Pampean agroecosystem
}

\author{
Sofia Graffigna ${ }^{1,2,3}$, Hugo J. Marrero ${ }^{2,3}$, Juan P. TORretta ${ }^{4,5}$ \\ ${ }^{1}$ Departamento de Biología, Bioquímica y Farmacia, Universidad Nacional del Sur, San Juan 670, 8000, Bahía Blanca, \\ Argentina \\ ${ }^{2}$ Laboratorio de Interacciones Bióticas en Agroecosistemas, (LIBA), Bahía Blanca, Argentina \\ ${ }^{3}$ Centro de Recursos Naturales Renovables de las Zonas Semiáridas, CONICET, Camino de la Carrindanga Km. 7 , \\ 8000, Bahía Blanca, Argentina \\ ${ }^{4}$ Facultad de Agronomía, Cátedra de Botánica General, Universidad de Buenos Aires, Av. San Martín 4453, C1417DSE, \\ Buenos Aires, Argentina \\ ${ }^{5}$ Consejo Nacional de Investigaciones Científicas y Técnicas, Buenos Aires, Argentina
}

Received 1 April 2020 - Revised 27 August 2020 - Accepted 29 September 2020

\begin{abstract}
Glyphosate is the most widely used herbicide worldwide and it could have negative effects on wild bees. We study the effect of glyphosate commercial formulation on the nesting behavior of wild solitary bees (Megachile spp.) and the survival of immature stages in a Pampean agroecosystem. In four plots without agricultural management located in an agricultural field, we placed 480 wooden trap-nests. The traps were sprayed with two different concentrations of glyphosate commercial formulation and only with water. The number of cells per nest was significantly lower in glyphosate treated traps compared with the water treatment. The probability of finding breeding cells was two times higher in nests without glyphosate commercial formulation compared with treated nests. Larvae completed their development and emerged as adults approximately four times more in nests without glyphosate commercial formulation, relative to those with glyphosate. Our results indicate that glyphosate commercial formulation could be conditioning the behavior of the nesting females and it is affecting their reproduction.
\end{abstract}

\section{Agrochemical effects / Megachile / Bee survival / Trap nests / Agricultural management}

\section{INTRODUCTION}

The use of land for agricultural purposes transformed nearly $50 \%$ of land surface in only 300 years (Ellis et al. 2010). This transformation, product of deterministic factors (such as

Electronic supplementary material The online version of this article (https://doi.org/10.1007/s13592-020-00816-8) contains supplementary material, which is available to authorized users.

Corresponding author: S. Graffigna, sofigraffigna@gmail.com

Manuscript Editor: Monique Gauthier agricultural expansion and agrochemicals) and stochastic factors (such as natural habitats loss and fragmentation), is the main cause of biodiversity change and loss worldwide (Sala et al. 2000; Tscharntke et al. 2005). Pollination, an important ecosystem service, is affected by these changes (Tscharntke et al. 2005; Potts et al. 2010) and some strategies are used to counteract these effects. For example, the management of crop edges was proposed to increase abundance and diversity of pollinators and thus improve pollination quality (Sáez et al. 2014). Although crops edges have a limited extension, these places are important biodiversity reservoirs (Hendrickx et al. 2007; Billeter et al. 
2008; Torretta and Poggio 2013). Crop edges usually have destructive management (Torretta and Poggio 2013), where both herbicides and insecticides are used to control spontaneous plants and non-beneficial arthropods (Gill and Garg 2014; Bartomeus and Bosch 2018). Therefore, it is necessary to establish how current agricultural management can affect the development of pollinator communities, and establish suitable management strategies for crop edges.

The current model of agricultural production uses large amounts of agrochemicals that might directly or indirectly affect pollinator communities and other organisms in agroecosystem such as honeybee (Apis mellifera L.) or wild bees (Gary et al. 1972; Kopit and Pitts-Singer 2018; Rosanigo et al. 2020); larvae and adults of toads (Cauble and Wagner 2005, Bernal et al. 2009); and fishes (Marques et al. 2014). Particularly in pollinators, direct effects are associated with the reduction of population abundance, cognitive changes, decreased in longevity and in visual abilities, among others (Boily et al. 2013; Herbert et al. 2014). On the other hand, indirect effects are associated with reduction of availability of floral and nesting resources (Devillers et al. 2002). Although several studies reported these effects, the majority were conducted in the laboratory and with managed pollinators such as honeybees or different species of Bombus (Mullin 2015) with few examples including wild bees. However, the recommended agrochemical dose may not have effects on managed bees (Thompson et al. 2014), but may be lethal in wild bees which are less adapted to agricultural management. Recently, Rosanigo et al. (2020) reported a diminished reproductive success of Megachile (Pseudocentron) gomprenoides Vachal in built nests in agricultural lots (principally: soybean) compared with built nests in seminatural areas paired. For this reason, studies in situ and with wild bees become indispensable.

Glyphosate (N-phosphonomethyl-glycine, $\mathrm{C}_{3}$ $\mathrm{H}_{8} \mathrm{NO}_{5} \mathrm{P}$, CAS 1071-83-6) is a broad-spectrum herbicide. In the case of glyphosate (and other agrochemicals), active ingredients are combined with other ingredients (e.g., adjuvants) to create the commercial formulae (Chaufan et al. 2014). An adjuvant is generally broadly defined as any substance separately added to a pesticide product that will improve the performance of the product (Coalova et al. 2014). Glyphosate commercial formulation (hereafter: GLY-CF) is mainly used to keep crops edges free of spontaneous weeds and to clear land for crop production. In addition, GLY$\mathrm{CF}$ is used in urban and peri-urban areas for the same purposes since it is a chemical that is economically cheap, easy to use and find in agrochemical markets (Abraham et al. 2018). This herbicide affects honeybees and could affect pollinators that use these semi-natural habitats as refugia and/or nesting sites (Kopit and Pitts-Singer 2018, but see Thompson et al. 2014). Sublethal doses of glyphosate deteriorate cognitive functions in honeybees, leading for example a taste decrease (Eiri and Nieh 2012), and infield-realistic doses damage the recovery of memory acquired during exploratory orientation flights (Balbuena et al. 2015). Ingestion of glyphosate at lower concentrations than those recommended by the manufacturer produced disorientation and deterioration of associative learning in workers of A. mellifera (Herbert et al. 2014; Balbuena et al. 2015). On the other hand, larvae of A. mellifera exposed to sublethal doses of glyphosate showed a delay in their development (Vázquez et al. 2018). Also, a recent study showed an increase in worker mortality of two species of social bees A. mellifera and Hypotrigona ruspolii (Magretti) (Apidae, Meliponini) after contact with plants sprayed with GLY-CF (Abraham et al. 2018 ). Despite the information available on the effects of glyphosate on managed bees, there are no studies that demonstrate the consequences of the use of this herbicide on solitary wild bees, which are relevant in crop pollination (Garibaldi et al. 2013).

The present study focused on trap nesting wild bees belonging to the genus Megachile (Megachilidae). All Megachile species are solitary and some of them build their nests in preexisting cavities in wood and hollow stems, among others (Michener 2007). Some studied species in the Pampean region use plant materials such as pieces of leaves, petals, and even chewed leaves for construction of brood cells or nest conditioning (Torretta and Durante 2011, Torretta et al. 2012, 2014). The number of brood cell per nest is variable and in each of them the females place a mass of pollen and one egg (Michener 2007). The aim of our study was to evaluate the 
effect of GLY-CF on the nesting behavior of solitary bees in a Pampean agroecosystem. In addition, we estimated the survival of immature stages (larvae, prepupae, and pupae) reared in trap nests exposed to different concentrations of GLYCF. Our hypothesis is that GLY-CF negatively affects the reproductive success of wild bees in agroecosystems through a reduction in the survival rate of immature stages. Our predictions are as follows: (i) female bees will indistinctly trap nests sprayed and not sprayed with GLY-CF (i.e., the females do not recognize the GLY-CF-impregnated trap nests); (ii) fertile females will build fewer brood cells per nests sprayed with GLYCF than those not sprayed; and (iii) there will be a negative relationship between survival of immature stages and the GLY-CF concentration applied to each trap nest.

\section{MATERIALS AND METHODS}

\subsection{Study area}

The study was carried out in an agroecosystem located in the Pampean region (S 35 56 $6^{\prime}$ W $61^{\circ}$ $11^{\prime}$, Buenos Aires province, Argentina). The Pampean region is a grassland turned into cultivated fields at rapid rate, affecting both landscape structure and land use patterns (Medan et al. 2011). The landscape is a mosaic of crop fields, and in lesser proportion sown pastures and semi-natural grasslands used for livestock grazing (Tognetti et al. 2010; Marrero et al. 2014) with scarce and small (agriculturally) unmanaged areas (henceforth restored fragments). The use of herbicides and pesticides is frequent in agricultural fragments which are predominant in this agroecosystem. Restored fragments (size range: $0.5-3$ ha) consisted of permanently fenced enclosures which had not been cultivated or grazed for the last 20 years and were therefore considered noncropped fragments (Tognetti et al. 2010).

\subsection{Sampling design}

The survey was carried out during monthly visits from December 2017 to April 2018. Four restored fragments were selected based on the great abundance of pollinators present in these sites, considering data obtained from a previous study (Rosanigo 2017; Rosanigo et al. 2020). Fragments whose areas vary between 0.5 and 1 ha (Pompozzi et al. 2019) were immersed in an agricultural matrix. In these semi-natural areas, vegetation is a grassland dominated by exotics grasses and some entomophilous plant species (Marrero et al. 2014; Rosanigo 2017). The restored fragments were separated by more than $1000 \mathrm{~m}$ in order to enhance their independence. At each restored fragment, 120 trap nests (40 by treatment, totaling 480 in all fragments) were placed in packages of eight traps each, containing two traps of four different diameters $(6,8,10$, and $12 \mathrm{~mm})$. Each trap nest consisted of a $2 \times 2 \times$ $12 \mathrm{~cm}$ block of wood with a $9 \mathrm{~cm}$ deep hole (Figure 1) (for a comparable approach see Dorado et al. 2011). Fifteen trap nest packages were placed per restored fragment and five of them were used in each treatment (normal, saturated, and control). The packages of trap nests of each treatment were separated by approximately $25 \mathrm{~m}$ within each restored fragment, and inside each treatment, packages were separated by a distance of two meters (Figure 1).

The treatments consisted of trap nests sprayed with two different concentrations of glyphosate commercial formulation Roundup ${ }^{\circledR}$ ControlMax: the "normal" treatment consisted of trap nests sprayed with the manufacturer recommended concentration ( $8 \mathrm{~g}$ GLY-CF $/ 1$ distilled water), "saturated" treatment in which the trap nests were sprayed with a solution with twice the recommended concentration (16 g GLY-CF / distilled water), and the "control" treatment consisted of trap nests sprayed only with distilled water. We used distilled water to eliminate the possible effects of the chemical components of tap water, as arsenic, which is present in water at our study site (Minaverry and Cáceres 2016). GLY-CF's doses were calculated based on normal field rates (CASAFE 2020). We used the saturated dose as a treatment in the present study, because untrained and/or poorly trained people usually use doses that largely exceed the normal dose (Abraham et al. 2018). Although it is not the recommended dose, it could be realistic.

In December 2017, the trap nest packages were installed and sprayed with distilled water, 


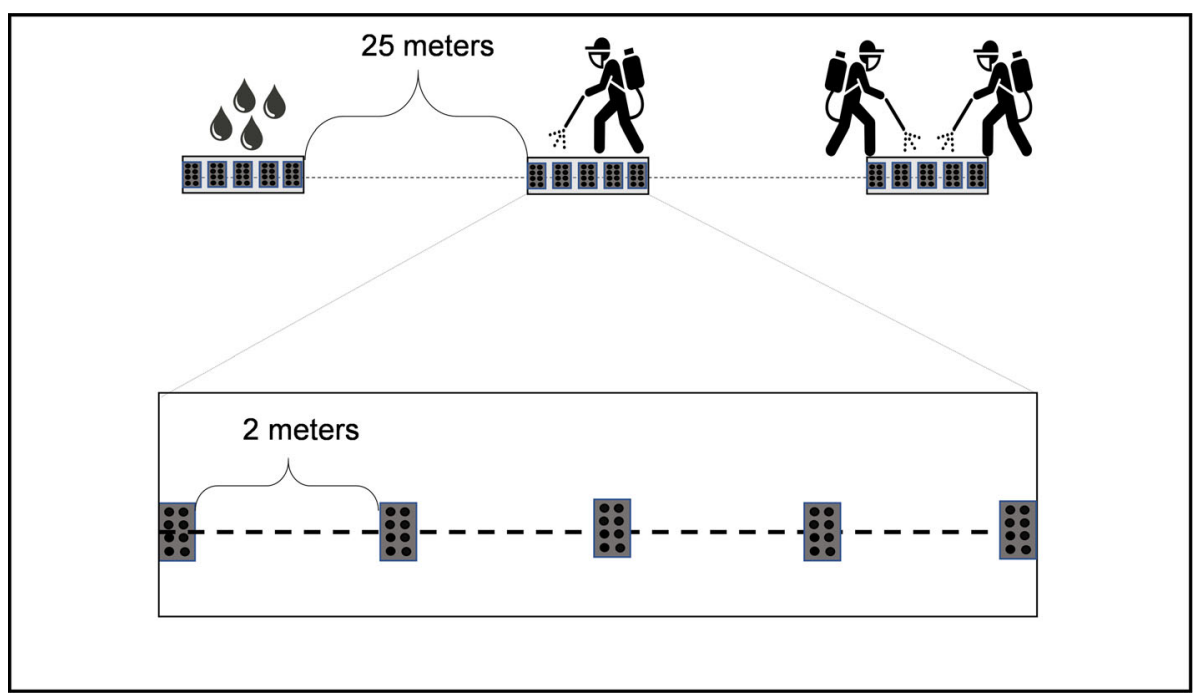

Figure 1. Scheme of disposition of traps nest in each restored fragment. The packages of trap nests of each treatment were separated by approximately $25 \mathrm{~m}$ within each restored fragment, and inside each treatment, packages were separated by a distance of two meters.

"normal" and "saturated" GLY-CF. For this purpose, we used different sprayers, one for each treatment, taking all precautions required to handle the herbicide. The trap nests packages were sprayed completely, covering the entire external surface with the solution. Approximately 11 of solution was used for the packages of each treatment with glyphosate $(1000 \mathrm{ml} / 20$ packs $=50 \mathrm{ml} /$ pack and $50 \mathrm{ml} / 8$ nest traps $=6.25 \mathrm{ml} /$ trap nest) and the same volume of distilled water for the traps nest control treatment. This was repeated in January, February, and March 2018.

In each visit, each trap nest was checked to register the presence/absence of bee-constructed nests (Table S1). Subsequently, each trap nest was sprayed again, in the same way as in the first visit and regardless of whether it contained beeconstructed nests or not, in order to simulate what actually happens in a field under agricultural management (Figure 2). Currently, GLY-CF could be sprayed 1-3 times or more after the crop has emerged, leaving the crop unharmed but controlling all actively growing weeds (Benbrook 2016). Finally, during the last visit to the study site (April 2018), all nest traps were collected and taken to the laboratory. In the lab, the traps were opened to record the number of bee-constructed nests per treatment and the number of brood cells present in each constructed nest. The brood cells of each beeconstructed nest were individually placed in plastic tubes with a cotton plug inside boxes under laboratory conditions until adult emergence. Each plastic tube was labeled with the nest number, position of the cell within the nest (from 1 to $n$, with 1 being the first constructed cell), and "control," "normal," and "saturated" treatment. When the adults emerged, they were sacrificed and mounted on entomological pins for further determination. Eighteen months later, we opened the remaining cells and confirmed that larvae were dead.

\subsection{Analysis}

Bee-constructed nests were evaluated using data from all the traps. The probability of finding a nest $(0=$ without nest, or $1=$ with nests $)$ was considered. A nest was considered to be beeconstructed if it contained at least one brood cell. For the brood cells, the data of cells quantity in all traps (with and without nests) were used, considering a value of 0 for traps without nest. Finally, survival was estimated using only data from traps with nest, such as the number of cells that completed their development and resulted in emerged adults per nest. We obtained a bee survival value in each trap that contained at least one cell. 


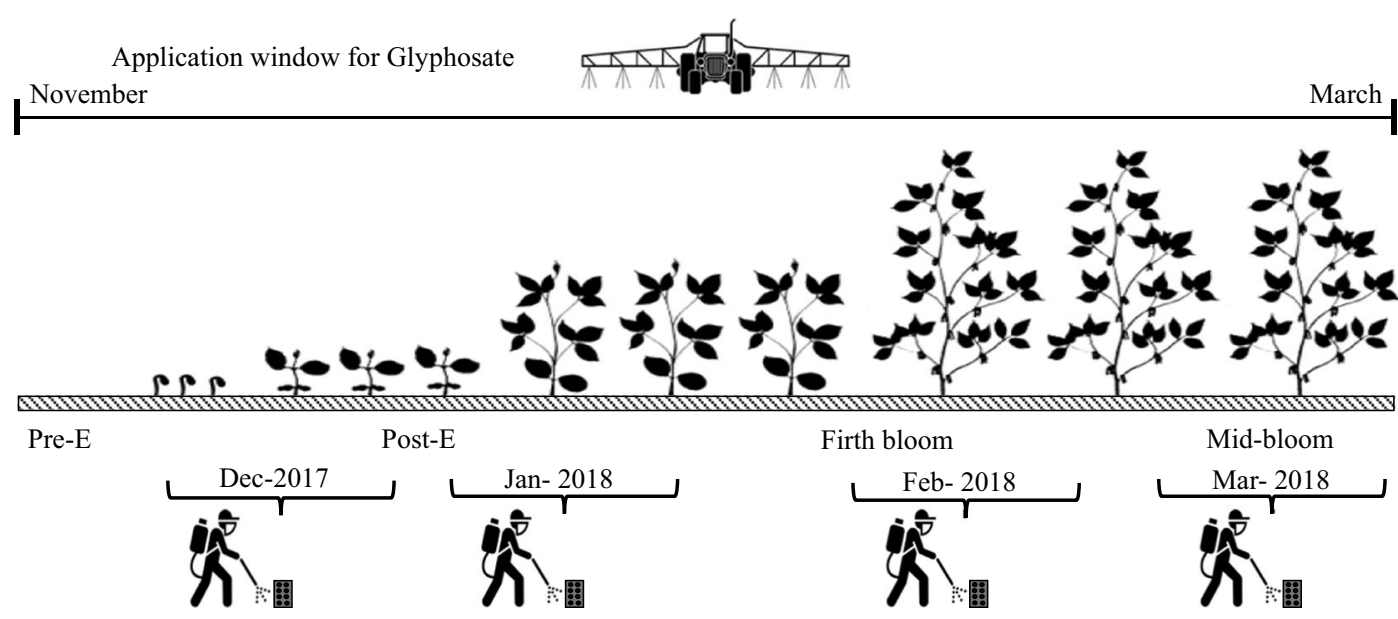

Figure 2. Scheme of application of GLY-CF on trap nest. The application window for GLY-CF in summer season crops in Pampas extends from the pre-emerged (pre-E) until the mid-bloom. To simulate the applications that occur in agricultural management, we sprayed traps-nest at four different times: the first two during the post-emerged (post-E) and the others during firth-bloom and mid-bloom. Our applications were intentionally synchronized with the fumigation of the associated crops.

Generalized linear and mixed models (GLMMs) were used to evaluate the bee-constructed nests, the number of brood cells, and the survival of immature stages (response variables). The $\mathrm{R}$ statistical software (R Development Core Team 2013) was used, with the glmer function of the lme4 package, with a binomial distribution for nest and survival and negative binomial distribution for number of cell (Table I). In the models, the concentrations of herbicide (normal, saturated, and control) were used as fixed factor (categorical variable), while the identity of the restored fragments, the package, and the diameter of the trap were used as nested random factors (Table I). Megachile species were not used as a random factor because one of the two species was very abundant and explained most of the variance. Overdispersion test was estimated with the dispersion glmer function of package blmeco, while the goodness of the models fit was performed using the DHARMa packages in $\mathrm{R}(\mathrm{R}$ Development Core Team 2013).

\section{RESULTS}

A total of 43 bee-constructed nests were found (occupation of approximately $9 \%$ of the total traps), of which 20 corresponded to control, 11 to normal concentration, and 12 to saturated concentration of
GLY-CF (Table S1). In total, 140 brood cells were found, 84 of which corresponded to the control, 30 to the normal, and 26 to the saturated treatment. The nests were occupied by two species of bees Megachile (Pesudocentron) gomphrenoides and Megachile (Dactylomegachile) sp. The most abundant species was $M$. gomphrenoides with more than $90 \%$ of the nests occupied by this species.

Models did not show overdispersion and presented an appropriate goodness of fit (Table I; Supplementary material, Fig. S1). No significant differences were found in the probability that a trap nest was occupied among the different treatments (ChiSquare $=4.502 ; p=0.105$ ) (Table II). However, significant differences were found in the number of built brood cells control vs. normal and saturated treatments (ChiSquare $=6.8693$; $p=0.03224)$. The number of brood cells in a nest without GLY-CF is more than twice in relation to the treated nests (Figure 3). Finally, survival of immatures stages also showed significant differences between treatments with GLY-CF and the control (ChiSquare $=11.248 ; p=0.0036$ ). The survival of the immature stages in the control nests was $52 \%$, while the nests treated with GLY-CF had a survival of $14 \%$ for the normal concentration and approximately $4 \%$ for the saturated one (Figure 4). 
Table I. Models used for the analysis. Response variables: nests, cells, and survival. Random factors: identity of the restored fragments (site), the group of traps (package), and the hole trap diameter (diameter). These variables were nested (1|site/package/diameter). Fixed factors: herbicide concentration (treatment). The overdispersion values (dispersion_glmer function of package blmeco) were computed as the square root of the penalized residual sum of squares divided by $n$, the number of observations. This quantity may be interpreted as the dispersion factor of a binomial and Poisson mixed model

\begin{tabular}{lllc}
\hline Model & Formula & Distribution & Overdispersion \\
\hline M1 & nests $\sim(1 \mid$ site/package/diameter $)+$ treatment & Binomial & 0.658 \\
M2 & cells $\sim(1 \mid$ site/package/diameter $)+$ treatment & Negative binomial & 0.505 \\
M3 & survival $\sim(1 \mid$ site/package/diameter $)+$ treatment & Binomial & 0.831 \\
\hline
\end{tabular}

\section{DISCUSSION}

Results show that our hypothesis related to the negative effects of GLY-CF on nesting biology of Megachile gomphrenoides and Megachile sp. was plausible. In accordance with our predictions, the probability of a female bee building a nest was not related to the use of GLY-CF, and both the number of brood cells per nest and the survival of the immature stages (larvae, prepupae, or pupae) were greater in nests constructed in GLY-CF free traps. Our results suggest that females of these bees select their nesting sites without considering the presence/ absence of GLY-CF. However, the total number of brood cells in the nests varies depending on GLY$\mathrm{CF}$ presence in nesting site. This result could be related to a cognitive failure of nesting females that, exposed to GLY-CF, fail to integrate the spatial information, and consequently make erroneous foraging trips. Therefore, it is difficult for these females to return to their nest, as it was reported for workers of honeybees (Boily et al. 2013; Balbuena et al. 2015). In this way, females of Megachile spp. could have established a nest and built one or few brood cells and then abandoned it, because they did not manage to return to the nest as a consequence of erroneous forage trips. Another possible explanation (non-mutually exclusive) is that adults in

Table 2. GLMM outputs. The table shows the outputs of generalized linear mixed-effects models with binomial (nests and survival) and negative binomial (cell) errors for the different response variables. There was one fixed factor: "treatment" (control, normal, and saturated); and three nested random factors: "site" (identity of the restored fragments), "package" (the group of traps) and "diameter" (the hole trap diameter)

\begin{tabular}{llllll}
\hline & Estimate & Standard error & $Z$ value & Probability $(>|z|)$ & Significance \\
\hline M1: nests & & & & & \\
Intercept & -2.9608 & 0.8272 & -3.579 & 0.000345 & $* * *$ \\
Normal & -0.8395 & 0.4459 & -1.883 & 0.059715 & \\
Saturated & -0.7247 & 0.4359 & -1.663 & 0.096372 & \\
M2: cells & & & & & $*$ \\
Intercept & -1.3712 & 0.8236 & -1.665 & 0.0959 & $*$ \\
Normal & -1.1779 & 0.5418 & -2.174 & 0.0297 & $*$ \\
Saturated & -1.3829 & 0.5742 & -2.408 & 0.0160 & $*$ \\
M3: survival & & & & & $*$ \\
Intercept & -0.6696 & 0.1875 & -3.571 & 0.000356 & $*$ \\
Normal & -1.3453 & 0.5644 & -2.384 & 0.017136 & 0.012484 \\
Saturated & -2.5885 & 1.0362 & -2.498 & & $*$ \\
\hline
\end{tabular}

$* 0.01, * * 0.001, * * * 0.0001$ 


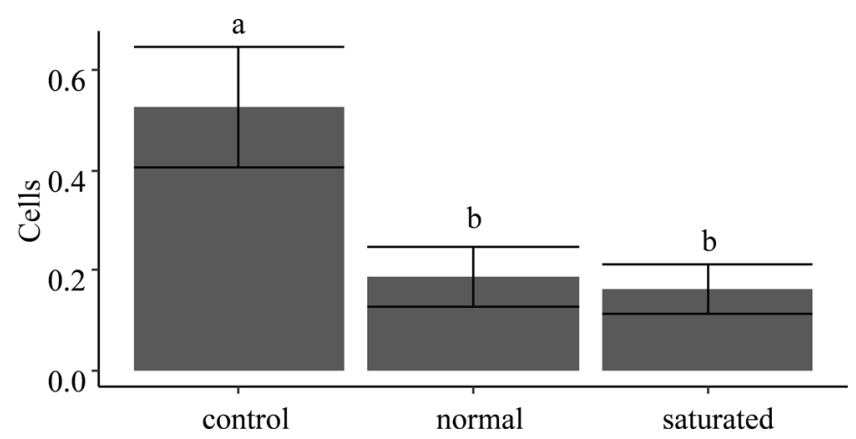

Figure 3. Number of built brood cells in nest sprayed with distilled water (control) or with different concentrations of GLY-CF (normal and saturated). The figure shows the mean $( \pm \mathrm{SD})$ number of brood cells per nest under different treatments.

contact with GLY-CF die before finishing their nests, as reported for social species (Abraham et al. 2018). It is possible that GLY-CF could be impregnated in the wood and affects females by direct contact. However, no dead adult bees were found inside the nests (although they might have died outside them). Also, numerous studies suggest that glyphosate and other agrochemicals intervene directly in the intestinal microbiota of bees, causing a reduction in bee survival (Dai et al. 2018; Motta et al. 2018; Vázquez et al. 2018; Blot et al. 2019).

The survival of immatures stages (i.e., the probability of emerging as adult) was four times higher in the GLY-CF free nests than ones treated with GLY$\mathrm{CF}$. This result could be explained by many studies carried out for other bee species. A similar trend of mortality was observed in a recent study under lab conditions in which Abraham et al. (2018) recorded about $25 \%$ of mortality in A. mellifera during the first $24 \mathrm{~h}$ of contact with plants sprayed with GLYCF. Mortality increased to $75 \%$ as so did the GLYCF concentration (Abraham et al. 2018). In another study, Dai et al. (2018) showed that the survival of the immature stages was lower for individuals fed diets with GLY-CF, also causing the decrease in larval weight. Vázquez et al. (2018) found that immature stages of $A$. mellifera that ate food with traces of glyphosate had a higher proportion of larvae with delayed molt and weight reduction, which could lead to a possible reduction in bee survival. However, contrary to these results, Thompson et al. (2014) found no significant effects on the survival, development, and average weight of larvae of A. mellifera, nor did they observe significant mortality in adult bees under different concentrations of GLY-CF.

Although all the studies cited here were carried out under laboratory conditions and using different

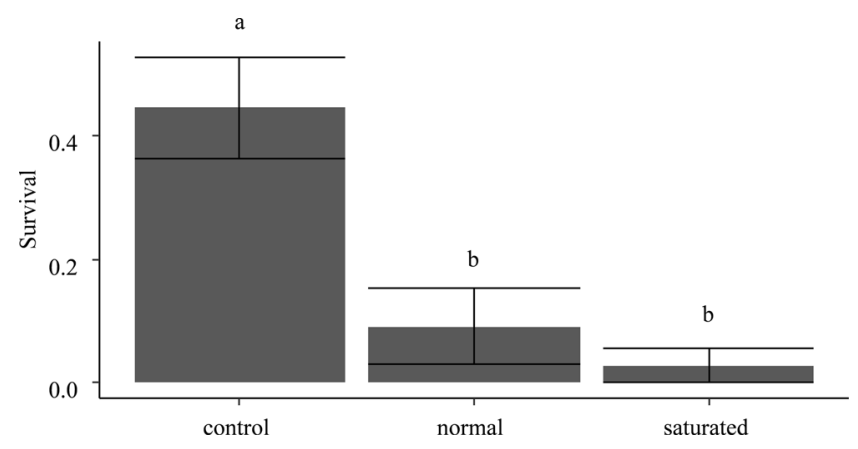

Figure 4. Survival (measured as emerged adults/constructed cells) of immature stages in treatments without (control) and with GLY-CF (normal and saturated). The figure shows the mean ( \pm SD) survival of immature stages per nest under different treatments. 
concentrations of agrochemicals, some of these recommended by the manufacturer, it is believed that in agricultural management recommendations are not (always) followed. The GLY-CF applications are made in many crops in excess, besides being applied by persons not trained in its use (Abraham et al. 2018). For this reason, we suggest field experimentation to evaluate in more realistic way agrochemicals effects on wild bees. It is possible that the combination of glyphosate with other agrochemicals may have negative synergistic effects on wild bees, as well as vary according to the entry route (Boily et al. 2013; Kopit and PittsSinger 2018). Moreover, the toxicity of the glyphosate formulation could be given not only by the active component but also by the presence of adjuvants, as observed by Chaufan et al. (2014) in their study with human cells. Coalova et al. (2014) demonstrated that the addition of an adjuvant to glyphosate formulation increases the toxicity of the mixture in cell human culture. On the other hand, in agroecosystems, the GLY-CF is prepared in tap water (in a different way to what was done here, where we used distilled water). Therefore, if the chemical components of tap water had any harmful effect on the bees, we would not be registering it. However, our results were similar to those reported by Rosanigo et al. (2020), who registered a higher mortality rate by unknown causes (i.e., not parasitism) of Megachile gomphrenoides in nests built in agricultural lots fumigated with GLY-CF prepared in tap water compared with semi-natural areas. These authors suggest that such results could be due to the use of agrochemicals (Rosanigo et al. 2020).

As a conclusion, it is important to emphasize studies like this one, since it is possible to use the results as a model to compare with other insects (Sgolastra et al. 2018). Our results, based only on obtained data in one study site and 1 year, suggest that the effects of GLY-CF are negative for these leaf cutter bee species. These results indicate an even greater risk compared with social species such as $A$. mellifera, because solitary bees in temperate areas exhibit uni- or bivoltine life cycles (Torretta et al. 2012, 2014) and the number of eggs laid by female bees is never more than two per day (Sgolastra et al. 2018). In addition, solitary bees have prolonged larval development and require different sites and materials for nesting (Torretta and Durante 2011, Torretta et al. 2012, 2014, Sgolastra et al. 2018). Likewise, the loss of a solitary female bee involves the loss of her whole offspring (Kopit and Pitts-Singer 2018). Finally, it is important to highlight the importance of species of native pollinators over the exotic managed species. Several studies suggest that, under favorable circumstances, native bees provide a service equivalent to honey bees for crops with high pollination requirements (Kremen et al. 2002; Garibaldi et al. 2013; Sponsler et al. 2019). In turn, native bees better cushion environmental fluctuations and are less vulnerable to outbreaks of different diseases (Kremen et al. 2002). On the other hand, they promote the persistence of native plants, which would allow slightly reducing the homogenization of landscapes (Garibaldi et al. 2013).

\section{ACKNOWLEDGMENTS}

We thank the University of Buenos Aires, for logistical support and permission to conduct this study at Estancia San Claudio. M. Sciberras, M.S. Balbuena, G. Peralta, and two anonymous reviewers made constructive comments on an earlier draft of this manuscript. R. Saurral helped with the English revision.

\section{AUTHORS' CONTRIBUTIONS}

SG, HJM, and JPT conceived this research and designed experiments; HJM and JPT wrote the paper and participated in the revisions of it. All authors read and approved the final manuscript.

\section{FUNDING}

Field work was supported by Agencia Nacional de PromociónCientífica y Tecnológica: grants PICT 2015-2523 and PICT 2017-3336. H.J.M. and J.P.T. are affiliated with CONICET.

La formulation commerciale du glyphosate affecte négativement le succès de la reproduction des abeilles sauvages solitaires dans un agroécosystème pampéen.

Effets agrochimiques / Megachile / survie des abeilles / nids-pièges / agriculture. 
Eine kommerzielle Glyphosphat-Formulierung hat einen negativen Einfluss auf den Reproduktionserfolg solitärer Bienen in einem Pampa-Ökosystem.

\section{Agrochemie-Effekte / Megachile / Überleben von Bienen / Nistfallen / Landwirtschaft.}

\section{REFERENCES}

Abraham, J., Benhotons, G.S., Krampah, I., Tagba, J., Amissah, C., et al. (2018). Commercially formulated glyphosate can kill non - target pollinator bees under laboratory conditions. Entomology Experimentalis et Applicata 166 (8), 695-702.

Balbuena, M.S., Tison, L., Hahn, M.L., Greggers, U., Menzel, R., et al. (2015). Effects of sublethal doses of glyphosate on honeybee navigation. Journal of Experimental Biology 218(17), 27992805 .

Bartomeus, I. \& Bosch, J. (2018). Pérdida de polinizadores: evidencias, causas y consecuencias. RevistaEcosistemas $27(2), 1-2$.

Benbrook, C.M. (2016). Trends in glyphosate herbicide use in the United States and globally. Environmental Sciences Europe 28(1), 3.

Bernal, M. H., Solomon, K. R. \& Carrasquilla, G. (2009). Toxicity of formulated glyphosate (Glyphos) and Cosmo-Flux to larval and juvenile Colombian frogs 2. Field and laboratory microcosm acute toxicity. Journal of Toxicology and Environmental Health, Part A, 72 (15-16), 966-973.

Billeter, R., Liira, J., Bailey, D., Bugter, R., Arens, P., et al. (2008). Indicators for biodiversity in agricultural landscapes: a pan - European study. Journal of Applied Ecology 45 (1), 141-150.

Blot, N., Veillat, L., Rouzé, R., Delatte, H. (2019). Glyphosate, but not its metabolite AMPA, alters the honeybee gut microbiota. PloS one 14 (4), e0215466.

Boily, M., Sarrasin, B., DeBlois, C., Aras, P., Chagnon, M. (2013). Acetylcholinesterase in honey bees (Apis mellifera) exposed to neonicotinoids, atrazine and glyphosate: laboratory and field experiments. Environmental Science and Pollution Research 20 (8), 56035614.

CASAFE (2020). Guía de productos fitosanitarios para la República Argentina. $19^{\circ}$ edición, CASAFE (www. casafe.org/publicaciones/guia-de-productosfitosanitarios).

Cauble, K. \& Wagner, R. S. (2005). Sublethal effects of the herbicide glyphosate on amphibian metamorphosis and development. Bulletin of Environmental Contamination and Toxicology 75 (3), 429-435.

Chaufan, G., Coalova, I., \& Ríos de Molina, M.C. (2014). Glyphosate commercial formulation causes cytotoxicity, oxidative effects, and apoptosis on human cells: differences with its active ingredient. International Journal of Toxicology 33 (1), 29-38.

Coalova, I., Ríos de Molina, M.C. \& Chaufan, G. (2014). Influence of the spray adjuvant on the toxicity effects of a glyphosate formulation. Toxicology in Vitro $\mathbf{2 8}$, 1306-1311.

Dai, P., Yan, Z., Ma, S., Yang, Y., Wang, Q., et al. (2018). The herbicide glyphosate negatively affects midgut bacterial communities and survival of honeybee during larvae reared in vitro. Journal of Agricultural and Food Chemistry 66 (29), 7786-7793.

Devillers, J., Pham-Delegue, M.H., Decourtye, A., Budzinski, H., Cluzeau, S., et al. (2002). Structuretoxicity modeling of pesticides to honey bees. SAR and QSAR in Environmental Research 13 (7-8), 641648.

Dorado, J., Vázquez, D.P., Stevani, E.L., Chacoff, N.P. (2011). Rareness and specialization in plantpollinator networks. Ecology 92 (1), 19-25.

Eiri, D.M. \& Nieh, J.C. (2012). A nicotinic acetylcholine receptor agonist affects honey bee sucrose responsiveness and decreases waggle dancing. Journal of Experimental Biology 215 (12), 2022-2029.

Ellis, E.C., Klein Goldewijk, K., Siebert, S., Lightman, D., Ramankutty, N. (2010). Anthropogenic transformation of the biomes, 1700 to 2000. Global Ecology and Biogeography 19(5), 589-606.

Garibaldi, L.A., Steffan-Dewenter, I., Winfree, R., Aizen, M.A., Bommarco, R., et al. (2013). Wild pollinators enhance fruit set of crops regardless of honey bee abundance. Science 339 (6127), 1608-1611.

Gary, N.E., Witherell, P.C., Marston, J. (1972). Foraging range and distribution of honey bees used for carrot and onion pollination. Environmental Entomology $1(1), 71-78$.

Gill, H.K., \& Garg, H. (2014). Pesticide: environmental impacts and management strategies. In: Larramendy, M.L. \& Soloneski, S. (eds.) Pesticides-Toxic Aspects, IntechOpen. doi: https://doi.org/10.5772/57399.

Hendrickx, F., Maelfait, J.P., Van Wingerden, W., Schweiger, O., Speelmans, M., et al. (2007). How landscape structure, land-use intensity and habitat diversity affect components of total arthropod diversity in agricultural landscapes. Journal of Applied Ecology 44 (2), 340-351.

Herbert, L.T., Vázquez, D.E., Arenas, A., Farina, W.M. (2014). Effects of field-realistic doses of glyphosate on honeybee appetitive behavior. Journal of Experimental Biology 217 (19), 3457-3464.

Kopit, A.M. \& Pitts-Singer, T.L. (2018). Routes of pesticide exposure in solitary, cavity-nesting bees. Environmental Entomology 47 (3), 499-510.

Kremen, C., Williams, N.M., Thorp, R.W. (2002). Crop pollination from native bees at risk from agricultural intensification. Proceedings of the National Academy of Sciences 99 (26), 16812-16816.

Marques, A., Guilherme, S., Gaivão, I., Santos, M. A., \& Pacheco, M. (2014). Progression of DNA damage 
induced by a glyphosate-based herbicide in fish (Anguilla anguilla) upon exposure and post-exposure periods - insights into the mechanisms of genotoxicity and DNA repair. Comparative Biochemistry and Physiology Part C: Toxicology \& Pharmacology, 166, 126133.

Marrero, H.J., Torretta, J.P., Medan, D. (2014). Effect of land use intensification on specialization in plant-floral visitor interaction networks in the Pampas of Argentina. Agriculture, Ecosystems \& Environment 188, 63-71.

Medan, D., Torretta, J. P., Hodara, K., Elba, B. \&Montaldo, N. H. (2011). Effects of agriculture expansion and intensification on the vertebrate and invertebrate diversity in the Pampas of Argentina. Biodiversity and Conservation 20 (13), 3077-3100.

Michener, C.D. (2007). The Bees of the World. 2nd edition. Johns Hopkins University Press, Baltimore.

Minaverry, C., Cáceres, V. (2016). La problemática del arsénico en el servicio de agua en la provincia de Buenos Aires, Argentina. Análisis de casos jurisprudenciales. Revista Internacional de Contaminación Ambiental 32 (1), 69-76.

Motta, E.V., Raymann, K., Moran, N.A. (2018). Glyphosate disturbs the gut microbiota of honey bees. Proceedings of the National Academy of Sciences 115 (41), 10305-10310.

Mullin, C.A. (2015). Effects of 'inactive' ingredients on bees. Current Opinion in Insect Science 10, 194-200.

Pompozzi G., Marrero H.J., Haedo J., Fritz L., Torretta J.P. (2019). Non-cropped fragments as important spider reservoirs in a Pampean agro-ecosystem. Annals of Applied Biology 175, 325-336

Potts, S.G., Biesmeijer, J.C., Kremen, C., Neumann, P., Schweiger, O., et al. (2010). Global pollinator declines: trends, and drivers. Trends in Ecology \& Evolution 25 (6), 345-353.

R Development Core Team. 2013 R: A Language and Environment for Statistical Computing R Foundation for Statistical Computing, Vienna, Austria. Available at: http://www.R-project.org/ .

Rosanigo, M.P. (2017). Importance of entomophilous plants from semi - natural environments for populations of bees and wild wasps in the Pampean Region. Thesis of Degree in Environmental Sciences, University of Buenos Aires. Agronomy Faculty.

Rosanigo M.P., Marrero H.J., Torretta J.P. (2020). Limiting resources on the reproductive success of a cavitynesting bee species in a grassland agroecosystem. Journal of Apicultural Research 59, 583-591.

Sáez, A., Sabatino, M., Aizen, M. (2014). La diversidad floral del borde afecta la riqueza y abundancia de visitantes florales nativos en cultivos de girasol. Ecología Austral 24 (1), 94-102.
Sala, O. E., Chapin, F. S., Armesto, J. J., Berlow, E., Bloomfield, J., Dirzo, R., et al. (2000). Global biodiversity scenarios for the year 2100 . Science 287 (5459), 1770-1774

Sgolastra, F., Hinarejos, S., Pitts-Singer, T.L., Boyle, N.K., Joseph, T., et al. (2018). Pesticide exposure assessment paradigm for solitary bees. Environmental Entomology 48 (1), 22-35.

Sponsler, D. B., Grozinger, C. M., Hitaj, C., Rundlöf, M., Botías, C., et al. (2019). Pesticides and pollinators: A socioecological synthesis. Science of The Total Environment $662,1012-1027$.

Thompson, H.M., Levine, S.L., Doering, J., Norman, S., Manson, P., et al. (2014). Evaluating exposure and potential effects on honeybee brood (Apis mellifera) development using glyphosate as an example. Integrated Environmental Assessment and Management 10 (3), 463-470.

Tognetti, P.M., Chaneton, E.J., Omacini, M., Trebino, H.J., León, R.J. (2010). Exotic vs. native plant dominance over 20 years of old-field succession on set-aside farmland in Argentina. Biological Conservation 143 (11), 2494-2503.

Torretta, J.P., Durante S.P. (2011). Nesting ecology of Megachile (Sayapis) mendozana Cockerell and its synonymous with Megachile (Sayapis) santiaguensis Durante (Hymenoptera: Megachilidae). Zootaxa 3008 (1), 63-68.

Torretta, J.P., Poggio, S.L. (2013). Species diversity of entomophilous plants and flower-visiting insects is sustained in the field margins of sunflower crops. Journal of Natural History 47 (3-4), 139-165.

Torretta J.P., S.P. Durante \& A.M. Basilio. (2014). Nesting ecology of Megachile (Chrysosarus) catamarcensis Schrottky (Hymenoptera: Megachilidae), a Prosopisspecialist bee. Journal of Apicultural Research 53, 590-598

Torretta, J.P., Durante, S.P., Colombo, M.G., Basilio, A.M. (2012). Nesting biology of the leafcutting bee Megachile (Pseudocentron) gomphrenoides (Hymenoptera: Megachilidae) in an agro-ecosystem. Apidologie 43 (6), 624-633.

Tscharntke, T., Klein, A.M., Kruess, A., Steffan-Dewenter, I., Thies, C. (2005). Landscape perspectives on agricultural intensification and biodiversity-ecosystem service management. Ecology Letters 8 (8), 857-874.

Vázquez, D.E., Ilina, N., Pagano, E.A., Zavala, J.A., Farina, W.M. (2018). Glyphosate affects the larval development of honeybees depending on the susceptibility of colonies. PloS one, 13(10), e0205074.

Publisher's note Springer Nature remains neutral with regard to jurisdictional claims in published maps and institutional affiliations. 